\title{
Notes on the vocalizations of Green Crombec (Sylvietta virens)
}

Peter Boesman

In the following we briefly analyze and compare voice of the different races of Green Crombec (Sy/vietta virens). We also try to quantify the extent of any vocal differences using the criteria proposed by Tobias et al. (2010), as a support for taxonomic review. We have made use of sound recordings available on-line from Xeno Canto (XC).

Our main aim is to compare song of morphologically distinct flaviventris with other races:
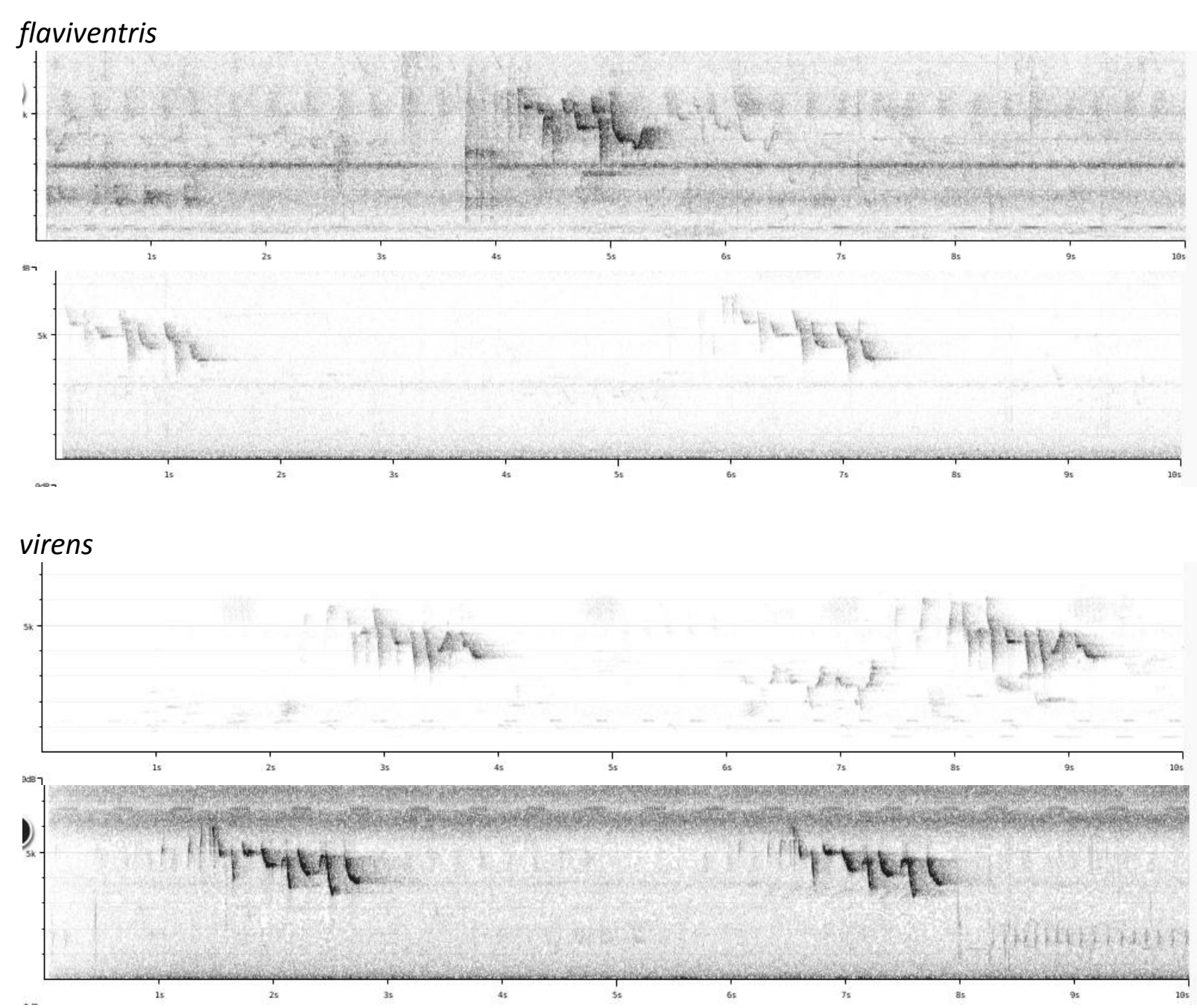

baraka

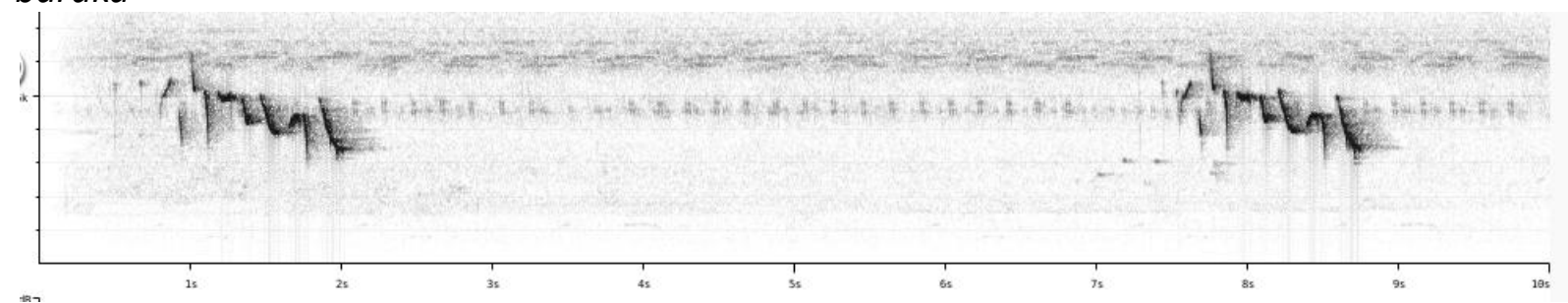



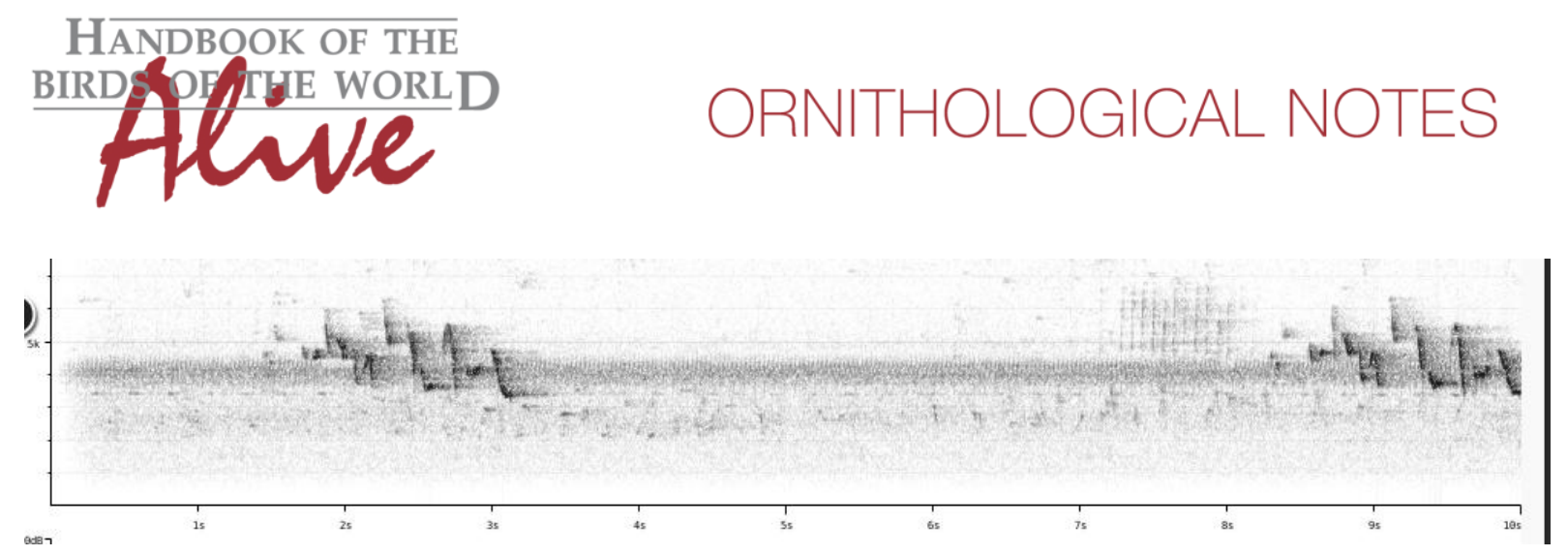

Song of all races is very similar, a short rather nervous melodious phrase, slightly descending in pitch and ending typically with a somewhat emphasized note lowest in (average) pitch. Almost all notes are in the range 3-6 kHz.

flaviventris does not seem to differ by any means.

We haven't found recordings of race tando.

This note was finalized on 9th February 2016, using sound recordings available on-line at that moment. We would like to thank in particular the sound recordists who placed their recordings for this species on XC: Jacob Cooper, Josh Engel, Phil Gregory, Hans Groot, Charles Hesse, Etienne Leroy, Mike Nelson, Niall Perrins, Bram Piot, Martin St-Michel and Crammy Wanyama.

\section{References}

Tobias, J.A., Seddon, N., Spottiswoode, C.N., Pilgrim, J.D., Fishpool, L.D.C. \& Collar, N.J. (2010). Quantitative criteria for species delimitation. Ibis 152(4): 724-746.

\section{Recommended citation}

Boesman, P. (2016). Notes on the vocalizations of Green Crombec (Sy/vietta virens). HBW Alive Ornithological Note 221. In: Handbook of the Birds of the World Alive. Lynx Edicions, Barcelona. (retrieved from http://www.hbw.com/node/932179 on 7 September 2016). 